\title{
PAIN AND ANXIETY IN CHILDREN RECEIVING ATRAUMATIC AND CONVENTIONAL RESTORATIVE DENTAL TREATMENT - A RANDOMIZED CLINICAL STUDY
}

\author{
DOR E ANSIEDADE EM CRIANÇAS QUE RECEBERAM TRATAMENTO \\ RESTAURADOR ATRAUMÁTICO E CONVENCIONAL - ESTUDO CLÍNICO \\ RANDOMIZADO
}

\author{
Regina de Nazaré Marreiros TAVARES ${ }^{1}$; Luciane ZANIN² Flávia Martão FLÓRIO $^{2}$ \\ 1. Postgraduate student at the São Leopoldo Mandic School of Dentistry and Research Center, Campinas, SP, Brazil; 2. Department of \\ Public Health Dentistry, São Leopoldo Mandic School of Dentistry and Research Center, Campinas, SP, Brazil; \\ flavia.florio@slmandic.edu.br
}

\begin{abstract}
The aim of this study was to assess previous anxiety and pain perceived by children while receiving atraumatic restorative treatment (ART) and conventional restorative treatment (CT). Seventy-nine children, aged between 5 and 8, who had at least two decayed deciduous molars, were selected. Each child agreed to the two kinds of treatment dispensed, one for each tooth and one for each treatment appointment, at random. The sample was distributed into two groups: Group 1 (G1) - children were submitted to CT in the first appointment and to ART in the second appointment - and; Group 2 (G2) - children were submitted to ART in the first appointment and to CT in the next appointment. The children reported dental anxiety before receiving the treatment and intensity of pain after the procedures, using the Facial Image Scale (FIS) and the Wong-Baker FACES ${ }^{\circledR}$ Pain Rating Scale, respectively. The heart rate was also measured before and during the procedures. The results demonstrated that anxiety (heart rate and FIS scale) exhibited a statistical difference in G1 $(\mathrm{p}<0.05)$, however, there was no difference between the groups when ART was performed first ( $p>0.05$ ). Children subjected to CT experienced higher levels of pain than those who were subjected to ART, regardless of the order of treatment $(\mathrm{p}<0.001)$. It was concluded, therefore, that ART possibly caused lower levels of pain in 5 to 8 year-old children when compared to CT, however, it did not reduce prior anxiety levels in the second session, using CT.
\end{abstract}

KEYWORDS: Pain perception. Dental anxiety. Dental atraumatic restorative treatment.

\section{INTRODUCTION}

One of the greatest challenges faced every day by the dentist in the treatment of child patients is the control of fear, anxiety and pain which, when present, results in negative behavior which hinders professional care, interfering with oral health and, consequently, the quality of life (BOEIRA et al., 2012; SIMON; BHUMIKA; NAIR, 2015).

Studies have shown that fear and anxiety arise more frequently in infancy due to caries, pain and previous treatment history (TICKLE et al., 2009; TORRIANI et al., 2014) and may persist as a vicious circle during adulthood, acting as a barrier to the establishment of oral health as it leads to delays and rejection of treatment, even at time when dentistry has at its disposal a variety of resources and advanced technologies (ARMFIELD, 2013).

Therefore, it is fundamental that the professional is prepared to identify pain, even in the absence of visible signs and given the limitations of the child to express it, thus avoiding the underestimation of the symptoms reported and to be able to offer the most suitable treatment (DA COSTA; RIBEIRO; CABRAL, 2012). A study has shown that the dentist is often not qualified to recognize dental pain in the child (DAHER; COSTA; COSTA, 2014) and, thus, the use of nonpainful procedures combined with attitudes that minimize the anxiety or phobia that the child experiences when undergoing dental work, may help with the management of this patient in the dental consulting room, establishing a satisfactory relationship between patient and professional with adherence to future dental treatment (DE MENEZES ABREU et al., 2011).

In this context, dental treatments such as atraumatic restorative treatment (ART), which is able to restore the tooth with minimal intervention and with little or no pain stimulation, would be able to promote greater acceptance, on the part of the patient, of treatment provided by the professional, cooperating with caries control without any stress to the child patient, as conventional treatment (CT), when using high/low-speed rotary drills and anesthesia, may cause pain and, consequently, anxiety and fear (AGUILAR et al., 2012). Several studies (RAHIMTOOLA et al., 2000; MICKENAUSTSCH; FRENCKEN; VAN'T HOF, 2007; GOUD et al., 2012; AGUILAR et.al., 2012) presented controversial results and, ultimately, did not arrive at a consensus over which restoration 
Pain and anxiety in children...

procedure was perceived by the patient as being more painful and causing more anxiety. In the designs, different individuals were considered for the composition of the study groups and did not take into account the possibility of a positive reinforcement of behavior when establishing a practitioner-patient relationship. In one of the studies (AGUILAR et al., 2012), split-mouth design was employed with a random order of treatment for the evaluation of two techniques: conventional and ART, however, the conventional technique was applied by one dentist while ART was applied by a different dentist, which could constitute a variable influencing the perception of treatment.

The present study aimed to investigate the previous anxiety and the perception of pain in children submitted to two randomized restoration techniques, ART and conventional treatment, applied by a single professional in a split-mouth model, considering that the pain threshold and the perception of anxiety are appropriate to each individual (LEMOS et al., 2012), in order to optimize procedures that combat anxiety and benefit continuity of treatment, thereby promoting oral health for patients of all ages.

\section{MATERIAL AND METHODS}

This study was a randomized clinical experimental trial with split-mouth design, developed in the dental clinics at the Escola de Aplicação of the Federal University of Pará, Brazil, approved by the research ethics committee of the São Leopoldo Mandic School of Dentistry and Research Center No. 484.155 and registered in the Brazilian Clinical Trials Registry Platform (REBEC) under number RBR-69ZXF4.

All children, legal guardians and parents received information on the purpose of the study and an explanation of the procedures to be performed, and signed an informed consent form. The study was conducted in accordance with principles for research involving humans, as defined by the Declaration of Helsinki.

A total of 77 children was required for the sample, based on the estimate of a $25 \%$ difference in the prevalence of pain and anxiety between conventional $(50 \%)$ and ART $(25 \%)$ treatments, considering a power of 0.8 and confidence level $(\alpha)$ of 5\% (DE MENEZES ABREU et al., 2011). For the sample selection, an epidemiologic survey of dental health was performed by a single calibrated investigator (Kappa $=0.8$ ) in five municipal schools in Belém, in the Brazilian state of Pará. Children aged between 5 and 8 years with at least two
TAVARES, R. N. M.; ZANIN, L.; FLÓRIO, F. M.

contralateral primary molars with active carious lesions (Black's class-II), presented no pain, no fistula, and a cavity opening large enough to use manual excavators were eligible for this study (DE MENEZES ABREU et al., 2011). The patient's general health was assessed by medical history, and those with systemic diseases and neurological disorders were excluded. After enrollment, 105 children attended the radiographic examinations (periapical/interproximal radiographs), of which 80 children, who presented teeth with a radiolucent image suggestive of occlusal decay with proximal extension, not exceeding $2 / 3$ of the area of dentin, without pulp or periapical involvement were selected (MOTTA et al., 2013).

The initial sample consisted of 80 children, however, only 79 children accepted the treatment without administration of local anesthesia on the days of appointments and, accordingly, these made up the final sample.

Both restoration techniques - ART and CT - were employed with each child by a single pediatric dentist over two clinical sessions. In the first session, a trained assistant performed a randomization by drawing out pieces of paper containing numbers to determine which tooth and which technique would be performed first, thereby forming the two trial groups: Group 1 (G1) children received $\mathrm{CT}$ at the first appointment and ART at the second appointment - and Group 2 (G2) - children received ART at the first appointment and $\mathrm{CT}$ at the next appointment.

Both treatments observed the following sequence, according to protocol:

ART - The removal of decayed tissue was performed with only hand instruments (ART Duflex Kit - SSWhite, Rio de Janeiro, Rio de Janeiro, Brazil), followed by the filling of the cavity with high viscosity glass ionomer cement (Vitro Molar NOVA DFL, Rio de Janeiro, Rio de Janeiro, Brazil) observing the protocol developed for this approach (FRENCKEN et al., 1996).

CT - Carbide drills nos. 245, 330, $1 / 4$ (KG - Sorensen, Cotia, São Paulo, Brazil) were used for opening the cavity and removing decayed tissue and were disposed of after use. The cavity was filled with amalgam (DFL Alloy - silver filings in capsule form - Nova DFL, Rio de Janeiro, Rio de Janeiro, Brazil) and amalgamator model Vibramat Capsular Digital (Schuster, Santa Maria, Rio Grande do Sul, Brazil), observing the preparation and restoration protocols for amalgam (MONDELLI et al., 2004). The protection of the dentin-pulp complex was performed on the cavities, 
Pain and anxiety in children...

using calcium hydroxide cement (Dycal - Dentsply, USA)

Anesthesia was performed only when necessary and when the patient requested it. Only one child submitted to conventional treatment in the second session received anesthesia during the removal of the decayed tissue, these data being excluded from the analysis.

\section{Evaluation of anxiety and pain}

In order to evaluate anxiety and pain, the use of an objective component was considered (evaluation of cardiac frequency), as well as subjective components for the measurement of anxiety - Facial Image Scale (FIS) (BUCHANAN; NIVEN, 2002), and of pain - Wong-Baker facial scale (WONG; BAKER, 1988). The scales were applied by a single trained assistant (Kappa $=0.85$ ) with a standardized approach in order to avoid "suggestive" bias.

At the first session, in the pediatric clinic waiting room, the assistant explained to each child, in plain language, the procedures that would be performed in the two appointments. The FIS (Facial Image Scale) was then applied, followed by the same question put to all the children: "which of these figures shows how you are feeling now while you are waiting to see the dentist?" (LEAL; ABREU; FRENCKEN, 2009). The children, subsequently indicated one of five options of drawings that most faithfully represented how they were feeling at that moment: from very happy $(=1)$ to very sad (=5).

Before the treatment began, the child was taken to the prevention room, where he/she was given a toothbrush and performed oriented toothbrushing, at which point the assistant fitted the frequency meter (model FT2, Polar Electro OY, Finland) around the chest and was tested, employing the first heart rate (HR) captured. The device was then turned off.

Next, the child was taken to the chair in the consulting room to start the procedure on the selected tooth. However the dentist was blinded to the face on the FIS scale chosen by the child. At the moment the procedure began, the frequency meter was turned on again and remained on until the procedure was over. The average (HR average) and peak (HR maximum) heart rate values, the time elapsed for the treatment procedures were recorded
TAVARES, R. N. M.; ZANIN, L.; FLÓRIO, F. M.

on the device. At the end of the restoration procedure, with the child still in the dental office chair, the assistant returned to the room and applied the Wong-Baker Facial Scale to evaluate pain, consisting of 6 figures that represent the varying degrees of pain with scores ranging from 0 (no pain) to 5 (extreme pain). The child was asked to indicate which figure corresponded most closely to the perceived sensations during the treatment received, but without mentioning the word "pain" (DE MENEZES ABREU et al., 2011).

In the second session, 7 days later (washout) (FOZ et al., 2011), the other treatment technique was performed on the pre-selected tooth, following the same sequence as in the first session: 1) Application of the FIS Scale; 2) Installation of the frequency meter and annotation of the initial heart rate; 3) Performance of the restoration procedure; 4) Annotation of the average and maximum heart rate values; 5) Application of the Wong-Baker Scale.

\section{Data Analysis}

The collected data were input to a Microsoft Office Excel 2010 spreadsheet and the analysis was conducted with the help of the Statistical Package for Social Sciences (SPSS) for Windows, version 20.0, and BioEstat version 5.0. The t-test for heart rate and time elapsed for the treatment procedures, and the Wilcoxon Test were used to analyze the pain and anxiety scales. For all analyses, a level of confidence $(\alpha)$ of $5 \%$ was applied.

\section{RESULTS}

The final sample consisted of 79 children with an average age of $6.6 \pm 1.2$, comprising 50 females and 29 males. A total of 158 primary molars were treated, 79 with ART and 79 with CT. Considering the randomization of procedures, in $46.8 \%$ of the patients, the ART was performed in the first clinical session (G2) and in $53.2 \%$, the CT was performed in the first session (G1). The mean values for the time taken to carry out the procedure were $18.74 \pm 3.99$ minutes for the ART and $17.42 \pm 3.43$ minutes for the $\mathrm{CT}(\mathrm{p}=0.003)$.

In G1, a significant difference was observed between the treatments in terms of heart rate values HR and HR max (Table 1) and in anxiety (Table 2). However, regardless of the order of treatment, the children reported more pain in the CT (Table 2). 
Table 1. Mean and standard deviation of heart rate in children participating in the study, according to the order and session of treatment. Belém, 2014.

\begin{tabular}{|c|c|c|c|c|c|c|c|}
\hline GROUP 1 & \multicolumn{3}{|c|}{ 1st session -CT } & \multicolumn{3}{|c|}{ 2nd session -ART } & \multirow[b]{2}{*}{$\mathbf{p}^{*}$} \\
\hline Heart rate & Mean \pm SD & Min & Max & Mean \pm SD & Min & Max & \\
\hline HR (bpm) & $99.4 \pm 12.6$ & 72 & 120 & $97.8 \pm 11.7$ & 73 & 112 & 0.161 \\
\hline HR avg (bpm) & $100.5 \pm 12.2$ & 76 & 129 & $95.0 \pm 9.6$ & 70 & 114 & $<0.001$ \\
\hline HRmax (bpm) & $121.3 \pm 17.5$ & 92 & 182 & $113.6 \pm 11.6$ & 92 & 145 & 0.006 \\
\hline GROUP 2 & \multicolumn{3}{|c|}{ 1st session - ART } & \multicolumn{3}{|c|}{ 2nd session - CT } & \\
\hline Heart rate & Mean \pm SD & Min & Max & Mean \pm SD & Min & Max & $\mathbf{p}^{*}$ \\
\hline HR (bpm) & $95.3 \pm 11.1$ & 78 & 120 & $98.7 \pm 11.8$ & 72 & 120 & 0.332 \\
\hline HRavg (bpm) & $95.5 \pm 9.9$ & 78 & 114 & $97.3 \pm 11.9$ & 70 & 121 & 0.195 \\
\hline HRmax (bpm) & $113.9 \pm 8.4$ & 99 & 143 & $118.6 \pm 15.7$ & 92 & 142 & 0.350 \\
\hline
\end{tabular}

bpm: beats per minute. $\mathrm{p}$ *: Test t ; HR: heart rate; HRavg: average heart rate; HRmax: maximum heart rate; SD: standard deviation; Min: minimum; Max: maximum.

Table 2. Median and interquartile range of FIS and Wong-Baker scales in children participating in the study, according to the order and session of treatment. Belém, 2014.

\begin{tabular}{|c|c|c|c|c|c|c|c|}
\hline \multirow[t]{2}{*}{ GROUP 1} & \multicolumn{3}{|c|}{ 1st session -CT } & \multicolumn{3}{|c|}{ 2nd session-ART } & \multirow[b]{2}{*}{$\mathbf{p}^{*}$} \\
\hline & Md $\pm I Q R$ & Min & Max & Md $\pm I Q R$ & Min & Max & \\
\hline FIS & $2.0 \pm 1.5$ & 1 & 5 & $1.0 \pm 1.0$ & 1 & 5 & 0.008 \\
\hline WONG-BAKER & $2.0 \pm 2.0$ & 0 & 5 & $0.0 \pm 1.5$ & 0 & 5 & $<0.001$ \\
\hline \multirow[t]{2}{*}{ GROUP 2} & \multicolumn{3}{|c|}{ 1st session -ART } & \multicolumn{3}{|c|}{ 2nd session -CT } & \\
\hline & Md $\pm I Q R$ & Min & Max & Md $\pm I Q R$ & Min & $\operatorname{Max}$ & $\mathbf{p}^{*}$ \\
\hline FIS & $2.0 \pm 1.25$ & 1 & 5 & $2.0 \pm 1.0$ & 1 & 5 & 0.403 \\
\hline WONG-BAKER & $0.0 \pm 2.0$ & 0 & 5 & $2.0 \pm 1.25$ & 0 & 5 & $<0.001$ \\
\hline
\end{tabular}

\section{DISCUSSION}

The study shows that each individual has a different perception of pain threshold and therefore reacts differently to the same painful stimuli and, moreover, the same individual may present different responses to various types of pain (DA COSTA; RIBEIRO; CABRAL, 2012). Taking into consideration the cognitive development of each child, it was decided to apply the split-mouth model for the evaluation of pain and anxiety perceived in both treatments (ART and CT), thus aiming to eliminate bias related to variability amongst individuals (FOZ et al., 2011). Unlike other studies (DE MENEZES ABREU et al., 2011; GOUD et al., 2012), the randomization of the restoration techniques in this paper was performed on the same child, which enabled not only more precise estimates, but also the requirement of a smaller number of individuals in the sample (FOZ et al., 2011).

Also different from other studies (DE MENEZES ABREU et al., 2011; AGUILAR et al., 2012), both techniques were applied by a single 
Pain and anxiety in children...

pediatric dentist in order to eliminate operator bias and take into consideration the emotional professional-patient relationship. Moreover, the period of 7 days between clinical sessions was established as the time interval (washout) between sessions, required in order to eliminate the residual effect of the first procedure carried over to the second session (FOZ et al., 2011).

The measurement of pain and anxiety variables took into consideration the neuropsychological and cognitive development appropriate to the age of the children in the sample, i.e. between 5 and 8 years old. Therefore, the Facial FIS (anxiety) and Wong-Baker (pain) scales were used as they were regarded as easy to understand and were well accepted by the child patients (BUCHANAN; NIVEN, 2002; LEMOS et al., 2011)

Initial heart rate (HR), taken before the beginning of each clinic session, did not vary with the type of treatment, probably due to the fact that it was measured outside the consulting room environment, before the child is seated in the dentist's chair for the performance of the procedure, proving that there were no differences in the level of anxiety at that moment in time.

In the analysis of the previous anxiety variable, the G1 demonstrated significant differences in heart rate (HR average, HR maximum) and in the FIS scale, since the children showed decreased anxiety levels at the second appointment and, although previous studies have shown that $\mathrm{CT}$ causes more discomfort and anxiety than ART (GOUD et al., 2012; MOTTA et al., 2013), this result was surprising, as it was expected that having a previous history of CT would have increased the anxiety scores. The time that elapsed for the first procedure associated with the intervention of the assistant, where she explained both procedures at the time of the first appointment, contributed to the result. A clinical trial reported that children who were treated with the air-motor and with Carisolv (chemomechanical caries removal) preferred the air motor because they reasoned that Carisolv would take longer than the air-motor (MARAGAKIS; HAHN; HELLWIG, 2001). DE MENEZES ABREU et al. (2011) showed similar results and highlighted the positive effect of CT on anxiety control, with decreased anxiety levels after appointments for restorative procedures.

Still on the topic of previous anxiety, it was observed that the children in G2 who received ART in the first session, did not show decreased heart rate (HR average and HR maximum) and FIS scale values in the second appointment (CT). Studies indicated that the use of manual instruments without
TAVARES, R. N. M.; ZANIN, L.; FLÓRIO, F. M.

the need for anesthesia during ART would make this technique more comfortable and more acceptable in the dental environment (LEAL; ABREU; FRENCKEN, 2009; AGUILAR et al., 2012); however, despite presenting low pain levels, ART did have a longer average procedure time, resulting in the mouth being kept open for a longer period of time during the first session, probably influencing the previous anxiety levels in the subsequent session. GEETHA PRYA et al. (2014) reported that the children submitted to protracted treatment during the caries removal procedure, presented scores of 3 and 4 on the FIS scale and they preferred the drill due to the shorter caries removal time.

The pain variable was associated with the type of treatment, irrespective of the order in which they were performed, showing that the children that received conventional treatment experienced more pain than those who received ART, which supports the findings of other papers (LEAL; ABREU; FRENCKEN, 2009; GOUD et al 2012; MOTTA et al., 2013; GEETHA PRYA et al., 2014). ART is considered to be one of the examples of the new paradigm - Minimally Invasive Dental Care - used to control decay and in the promotion of healthcare (SERPA et al., 2017).

Conventional restorations are widely employed in dentistry in the rehabilitation of decayed teeth, however, patients submitted to these procedures have reported pain, almost always due to the need to use drills and anesthesia (MOTTA et al., 2012), which, although it is indicated for the control of pain phenomena, is considered a trigger factor for anxiety, fear and pain, and one of the reasons for eschewing dental treatment (DA COSTA; RIBEIRO; CABRAL, 2012). In children, when anesthesia is required, it almost always triggers a negative response, most often involving bouts of crying and, therefore, during this study, and irrespective of the type of procedure, anesthesia was only administered when necessary or when the patient requested it, in line with similar criteria used in other studies (DE MENEZES ABREU et al., 2011; AGUILAR et al., 2012).

Through the evaluation of pain and anxiety in children, this paper aimed to offer support to cope with one of the biggest challenges in dental care, namely the patient's acceptance of dental treatment; however, it is important to recognize some of the limitations of this study, such as the lack of knowledge of the children's past treatment history, history of family anxiety, interaction with the dental office environment and familiarity with the dental procedures, for these are factors that may interfere with the children's response to anxiety and dental 
pain (OLIVEIRA et al., 2010; LEMOS et al., 2011; SIVIERO et al., 2013). It is suggested, therefore, that future studies should include questionnaires for the collection of these data so that they may be taken into consideration in the analysis.

Although there is a strong correlation between anxiety and caries experience, inasmuch as studies show that children who present low dmft scores (0-3) are less anxious than those with medium (4-6) and high ( $\geq 7) \mathrm{dmft}$ scores (NICOLAS et al., 2010; OLAK et al.; 2013), the present study strictly observed the volunteer selection criteria, considering tooth and cavity-related characteristics, resulting from the variables studies and the "splitmouth" design and, accordingly, the children presented with the same pattern of caries severity, which may not have interfered with the results. The intervention by the assistant when explaining the restorative techniques to the children, prior to the application of the FIS scale and the use of the frequency meter, may have interfered with anxiety levels. However, as the procedure was adopted for both groups, it is assumed that the effects of this intervention on the children's previous anxiety were similar, and did not lead to any bias in the results.

Treatment decisions often depend on the dental health condition of the patient. ART restorations successfully contribute to controlling tooth decay control and to health care, and they may be employed as definitive restorations in class I and II cavities, including both primary and permanent molars, since they have a survival rate similar to that of amalgam, three years on average. (TAIFOUR et al., 2002). However, the success of the technique depends on the ability of the practitioner to execute it according to a rigid protocol, to the quality of the material employed and the adequate removal of the decayed tissue (FRENCKEN et al., 1996). Extensive caries lesions that encompass multiple tooth surfaces still constitute the biggest challenge to ART restorations due to this material's low fracture resistance (TAIFOUR et al., 2002).

The professional, when making his/her decision, must also take into consideration psychosocial factors related to the patient, mainly where children are involved. In this context, ART is much more accepted by children and must be used by the dentist as his first option whenever this indication is possible, as the levels of pain are lower with this technique than with conventional techniques, according to the results presented. Other factors, however, should be taken into account at this time, such as prior negative experiences, the presence of anxiety and oral health conditions. Anxious children with indications of pain find it difficult to endure lengthy treatment, so CT combined with the use of anesthetic would perhaps be the better option.

\section{CONCLUSION}

ART presented lower levels of pain than CT for both groups, but children who received ART at the first appointment continued to show the same degree of anxiety in the second appointment, probably because the ART technique involved longer procedure.

\section{ACKNOWLEDGEMENTS}

We thank the children, their parents and the assistant who took part in this study. This study has been supported by the Escola de Aplicação of Federal University of Pará, Brazil.

RESUMO: O objetivo desse trabalho foi avaliar a ansiedade prévia e a dor percebida por crianças submetidas ao tratamento restaurador atraumático (TRA) e ao tratamento convencional (TC). Foram selecionadas 79 crianças de 5 a 8 anos de idade que possuíam até dois molares decíduos cariados. Cada criança recebeu os dois tipos de tratamento, um para cada dente selecionado, distribuídos, randomicamente, um em cada sessão. A amostra foi dividida em dois grupos: Grupo 1 (G1) - crianças que realizaram o TC na primeira sessão e o TRA na segunda sessão - e; Grupo 2 (G2) - crianças que realizaram TRA na primeira sessão e TC na sessão seguinte. A criança reportou a ansiedade antes de receber o tratamento e a intensidade da dor após os procedimentos através da escala Facial Image Scale (FIS) e a escala de faces de WongBaker respectivamente. A frequência cardíaca também foi mensurada antes e durante os procedimentos. Os resultados demonstraram que a ansiedade (frequência cardíaca e escala FIS) apresentou diferenças estatísticas no G1 (p<0.05), porém permaneceu sem diferenças no G2 ( $>0.05)$. As crianças que receberam o TC experimentaram níveis de dor maiores que aquelas que receberam o TRA, em ambos os grupos $(\mathrm{p}<0.001)$. Conclui-se que o TRA causou menores níveis de dor em crianças de 5 a 8 anos de idade, porém não reduziu os níveis de ansiedade prévia para uma segunda sessão com TC.

PALAVRAS-CHAVES: Percepção de dor. Ansiedade dental. Tratamento dental restaurador atraumático. 


\section{REFERENCES}

AGUILAR, A. A. A.; CARO, T. E. R.; SAAVEDRA, J. H.; FRANÇA, C. M.; FERNANDES, K. P. S.; MESQUITA-FERRARI, R. A.; BUSSADORI, S. K. La práctica restaurativa atraumática : uma alternativa dental bien recibida por los niños. Revista Panamericana de Salud Publica, Washington DC, v. 31, n. 2, p. $148-52,2012$.

ARMFIELD, J. M. What goes around comes around: revisiting the hypothesized vicious cycle of dental fear and avoidance. Community Dentistry and Oral Epidemiology, Copenhagen, v. 41, p. 279-287, 2013. https://doi.org/10.1111/cdoe.12005

BOEIRA, G. F.; CORREA, M. B.; PERES, K. G.; PERES, M. A.; SANTOS, I. S.; MATIJASEVICH, A.; BARROS, A. J. D.; DEMARCO, F. F. Caries is the main cause for dental pain in childhood: findings from a birth cohort. Caries Research, New York, v. 46, n. 5, p. 488-495, 2012. https://doi.org/10.1159/000339491

BUCHANAN, H.; NIVEN, N. Validation of a facial image scale to assess child dental anxiety. International Journal of Paediatric Dentistry, New Delhi, v. 12, n. 1, p. 47-52, 2002. https://doi.org/10.1046/j.09607439.2001.00322.x https://doi.org/10.1046/j.0960-7439 .2001.00322.x

CARRILLO-DIAZ, M.; CREGO, A.; ARMFIELD, J.M.; ROMERO-MAROTO, M. Treatment experience, frequency of dental visits, and childrens dental fear : a cognitive approach. European Journal of Oral Sciences, Copenhagen, v. 120, n. 1, p. 75-81, 2012. https://doi.org/10.1111/j.1600-0722.2011.00921.x

DA COSTA, R. S. M.; RIBEIRO, S. N.; CABRAL, E. D. Determinants of painful experience during dental treatment. Revista Dor, São Paulo, v. 13, n. 4, p. 365-70, 2012.

DAHER, A.; COSTA, M.; COSTA, L. R. Factors associated with paediatric dentist' perception of dental pain in pre-schoolers: a mixed-methods study. International Journal of Paediatric Dentistry, New Delhi, v. 25, n. 1, p. 51-60, 2014. https://doi.org/10.1111/ipd.12099

MARAGAKIS, G. M.; HAHN, P.; HELLWIG, E. Clinical evaluation of chemomechanical caries removal in primary molars and its acceptance by patients. Caries Research, New York, v. 35, n. 3, p. 205-10, may./ jun. 2001.

DE MENEZES ABREU, D. M.; LEAL, S. C.; MULDER, J.; FRENCKEN, J. E. Pain experience after conventional, atraumatic, and ultraconservative restorative treatments in 6- to 7-yr-old children. European Journal of Oral Sciences, Copenhagen, v. 119, n. 2, p. 163-68, 2011. https://doi.org/10.1111/j.16000722.2011.00806.x

DE MENEZES ABREU, D. M.; LEAL, S. C.; MULDER, J.; FRENCKEN, J. E. Patterns of dental anxiety in children after sequential dental visits. European Archives of Paediatric Dentistry, London, v. 12, n. 5, p. 250-54, 2011. https://doi.org/10.1007/BF03262827

FOZ, A. M.; FERREIRA JR, S. B.; PONCHIO, J.; GONÇALVES, R. P.; PANNUTI, C. M.; DE LIMA, L. A. P. A. Clinical trial designs in dental in dental researches. Brazilian Journal of Periodontology, Rio de Janeiro, v. 21, n. 4, p. 46-54, 2011.

FRENCKEN, J. E.; PILOT, T.; SONGPAISAN, Y. PHANTUMVANIT, P. Atraumatic Restorative Treatment (ART): rationale, technique and development. Journal of Public Health Dentistry, Raleigh, U.S., v. 56, n. 3, p. 135-40, 1996.

GEETHA PRIYA, P. R.; SHARATH, A.; BABY JOHN, J.; PUNITHAVATHY, R.; KARTHICK, K. Comparison of behavioral response to caries removal methods: a randomised controlled cross over trial. Journal of the Indian Society of Pedodontics and Preventive Dentistry, Chandigarh, India, v. 32, n. 1, p. 48-52, 2014. https://doi.org/10.4103/0970-4388.127055 
GOUD, R. S.; NAGESH, L.; SHOBA, F.; RAJU, H. G. Assessment of discomfort experienced by school chidren while performing art and mcp - an experimental study. Journal of Dentistry, Tehran, Iran, v. 9, n. 4, p. 229-37, 2012.

LEAL, S. C.; ABREU, D. M. M.; FRENCKEN, J .E. Dental anxiety and pain related to ART. Journal of Applied Oral Science, Bauru, v. 17, Supplement, p. 84-88, 2009. https://doi.org/10.1590/S167877572009000700015

LEMOS, B.; ROSA, S.; MARINHO, A. R.; LOURENÇO, I. O.; DE ANDRADE, M. A dor do paciente pediátrico no consultório dentário. Acta Pediátrica Portuguesa, Lisboa, v. 42, n. 3, p.123-8, 2011.

MICKENAUSTSCH, S.; FRENCKEN, J. E.; VAN'T HOF, M. Atraumatic restorative treatment and dental anxiety in outpatients attendingpublic oral health clinics in South Africa. Journal of Public Health Dentistry, Raleigh, U.S., v. 67, n. 3, p. 179-184, 2007.

MONDELLI, J.; FRANCO, E. B.; ISHIKIRIAMA, A.; PEREIRA, J. C.; FRANCISCHONE, C. E.; MONDELI, R. L.; NAVARRO, M. F. L; VALERA, R. C.; SOUZA JUNIOR, M. H. S; CARVALHO, R. M.; ATTA, M. T. Dentística procedimentos pré-clínicos. 3. ed. São Paulo: Santos, 2004, 266p.

MOTTA, L. J.; BUSSADORI, S. K.; CAMPENELLI, A. P.; DA SILVA, A. L.; ALFAYA, T. A.; DE GODOY, C. H. L.; NAVARRO, M. F. L . Randomized controlled clinical trial of long-term chemo-mechanical caries removal using papacarie TM gel. Journal Applied of Oral Science, Bauru, v. 22, n. 4, p. 307-313, 2014. https://doi.org/10.1590/1678-775720130488

NICOLAS, E.; BESSADET, M.; COLLADO, V.; CARRASCO, P.; ROGERLEROI, V.; HENNEQUIN, M. Factors affecting dental fear in French children aged 5-12 years. International Journal of Paediatric Dentistry, Oxford, v. 20, n. 5, p. 366-73, sep. 2010. https://doi.org/10.1111/j.1365-263X.2010.01054.X

OLAK, J.; SAAG, M.; HONKALA, S.; NÕMMELA, R.; RUNNEL, R.; HONKALA, E.; KARJALAINEN, S. Children's dental fear in relation to dental health and parental dental fear. Stomatologija, Baltic Dental and Maxillofacial Journal, Kaunas, Lithuania, v. 15, n. 1, p. 26-31, 2013.

OLIVEIRA, R.S.; TORRES, L.M.S; GOMES, I.S.; NICOLÓ, R.D. Evaluation of anxiety levels in chidren during odontologic treatment. International Journal of Dentistry, Cairo, v. 9, n. 4, p. 193-97, 2010.

RAHIMTOOLA, S.; VAN AMEROGEN, W. E.; MAHER, R.; GROEN, H. Pain related to diferente ways of minimal intervention in the treatment of small caries lesions. ASDC Journal of Dentistry for Children, Chicago, v. 67, n. 2, p. 123-127, 2000.

SERPA, E. B. M.; CLEMENTINO, M. A.; GRANVILLE-GARCIA, A. F.; ROSENBLATT, A. the effect of atraumatic restorative treatment on adhesive restorations for dental caries in deciduous molars. Journal of Indian Society of Pedodontics and Preventive Dentistry, Chandigarh, v. 35, n. 2, p. 167-173, 2017. https://doi.org/10.4103/JISPPD.JISPPD_98_16

SIMON, A. K.; BHUMIKA, T. V.; NAIR, N. S. Does atraumatic restorative treatment reduce dental anxiety in children? A systematic review and meta-analysis. European Journal of Dentistry, Ankara, v. 9, n. 2, 2015.

SIVIERO, P.; FOLEGATTI, C.; GIANNINI, L.; MASPERO, C. A ansiedade da criança no dentista : uma abordagem psicológica. Dentista Hoje, São Paulo, v. 1, n. 2, p. 36-39, 2013.

TAIFOUR, D.; FRENCKEN, J. E.; BEIRUTI, N.; VAN'T HOF, M. A.; TRUIN, G. J. Effectiveness of glassionomer (art) and amalgam restorations in the deciduous dentition - results after 3 years. Caries Research, Basel, v. 36, n. 6, p. 437-44, 2002. https://doi.org/10.1159/000066531 
TICKLE, M.; JONES, C.; BUCHANNAN, K.; MILSOM, K. M.; BLINKHORN, A. S.; HUMPHRIS, G. M. A prospective study of dental anxiety in a cohort of children followed from 5 to 9 years of age. International Journal Paediatric Dentistry, Oxford, n. 19, v. 4, p. 225-232, 2009. https://doi.org/10.1111/j.1365263X.2009.00976.x

TORRIANI, D. D.; BONOW, M. L. M.; SANTOS, I. S.; MATIJASEVICH, A.; BARROS, A. J.; DEMARCO, F. F.; PERES, K. G. Dental caries is associated with dental fear in childhood: findings from a birth cohort study. Caries Research, Basel, v. 48, n. 4, p. 263-270, 2014. https://doi.org/10.1159/000356306

VERSLOOT, J.; VEERKAMPS, J. S.; HOOGSTRATEN, J.; MARTENS, L. C. Dental fear in children may be related to previous pain experience during dental treatment. Community Dentistry of Oral Epidemiology, Copenhagen, v. 32, n. 6, p. 456-61, 2004. https://doi.org/10.1111/j.1600-0528.2004.00187.x

WONG, D. L.; BAKER, C. M. Pain in children : comparison of assessment scales. Pediatric Nursing, Pitman, v. 14 , n. 1, p. 9-17, 1988. 